Original Research Paper

\title{
Municipal Solid Waste Generation and its Management, a Growing Threat to Fragile Ecosystem in Kashmir Himalaya
}

\author{
${ }^{1}$ Rouf Ahmad Bhat, ${ }^{1}$ Moonisa Aslam Dervash, \\ ${ }^{1}$ Mohammad Aneesul Mehmood and ${ }^{2}$ Khalid Rehman Hakeem \\ ${ }^{I}$ Division of Environmental Sciences, \\ Sher-e-Kashmir University of Agricultural Sciences and Technology, Shalimar, Kashmir-190025, India \\ ${ }^{2}$ Department of Biological Sciences, Faculty of Science, King Abdulaziz University, Jeddah, Saudi Arabia
}

Article history

Received: 16-08-2017

Revised: 04-12-2017

Accepted: 13-12-2017

Corresponding Authors:

Khalid Rehman Hakeem

Department of Biological

Sciences, Faculty of Science,

King Abdulaziz University,

Jeddah, Saudi Arabia

Email: kur.hakeem@gmail.com

\begin{abstract}
The Kashmir valley is facing tremendous pressure associated with problems of growing waste generation. Thus, the aim of the present research was to generate baseline data for adequate waste management and associated problems. For the collection of samples, 20 houses were randomly selected in the main town from each district and segregated into compostable, recyclable, combustible and inert categories. All the samples were transported with immense care to the laboratory for further analysis. Waste generation for the four districts with an average of $0.526 \mathrm{~kg} / \mathrm{capita} /$ day in Srinagar, $0.479 \mathrm{~kg} /$ capita/day in Anantnag, $0.400 \mathrm{~kg} /$ capita/day in Ganderbal and $0.397 \mathrm{~kg} / \mathrm{capita} /$ day in Budgam were determined during the current investigation. The total waste generated on annual basis observed in all the four districts was observed to be 57,199.99 Metric Tonnes (MT) with the highest $(236,732.75 \mathrm{MT})$ in Srinagar and the lowest of $(42,840.00$ MT) in Budgam. The waste constituent accounted highest $20-22 \%$ for food waste followed by cardboard and paper (11-15\%), wooden items (11-14\%). The major fraction of category waste comprised of recyclable (62-64\%), followed by compostable (20-21\%) and minor comprised of inert materials (3-4\%). In general, poor to negligible systems of waste collection, transportation and disposal were observed in all four districts. Srinagar was found as the lone district practicing landfilling of MSW in Achan area. Thus, the need of hour is to save the scenic beauty of fragile ecosystem from waste disposal hazard after adopting various strategies like segregation of waste at the source and statutory provisions.
\end{abstract}

Keywords: Waste, Recyclable, Food Waste, Waste Category, Fragile Ecosystem, Kashmir

\section{Introduction}

Most of the cities and health resorts in the world are experiencing unplanned urban sprawl and heavy pressure of population. The net result is an enormous generation of solid wastes. The quantity of generated solid waste mainly depends on population, economic growth and the efficiency of the reuse and recycling system. In 1947, cities and towns in India generated an estimated 6 million tons of solid waste which rose to 48 million tons in 1997 (NEERI, 1999). Rapid population growth and expanding urbanization have caused a drastic increase of the municipal solid waste generation and the variety of the waste composition (Nguyen et al., 2011). Municipal Solid Waste (MSW) consists of all types of solid waste generated by households and commercial establishments and collected usually by local government bodies
(Bhada-Tata and Hoornweg, 2011). The majority of substances composing MSW in developing countries include paper, kitchen waste, plastics, metals, textiles, rubber and glass. According to The solid waste composition in most Asian countries is highly biodegradable, mainly composed of an organic fraction with high moisture content (Visvanathan et al., 2004). Food waste, plastic/foam, paper, rubber/leather, wood/grass, metal, glass and textiles are the common MSW components. The generation of municipal solid waste in the mountainous regions has serious cascading effects on the lower valley. The generation of MSW during peak tourist influx (Hindu Pilgrimage; Yatra) at forest areas was too high, which could alter all environmental parameters if proper disposal could not occur at right time (Bhat et al., 2012). Often production of solid waste is the most serious threat to the fragile 
ecology of the mountainous environments (Jain, 1994). The increasing Municipal Solid Waste Management (MSWM) problems and its disposal strikes environment and health hazard due to prevailing scenario of waste handling practices and disposal (Bhat et al., 2012). Besides this, seasonal tourist inflow adds significantly to the demands on resource base and contributes considerably to the generation of MSW. Ecological impacts such as land degradation, water and air pollution are related to improper management of MSW (Khajuria et al., 2008).

MSWM encompasses planning, engineering, organization, administration, financial and legal aspects of activities associated with generation, storage, collection, transfer and transport, processing and disposal of municipal solid wastes in an environmentally compatible manner adopting principles of economy, aesthetics, energy and conservation (Tchobanoglous et al., 1993). In this regard situation in India is grim as more than $25 \%$ of the MSW is not collected at all; $70 \%$ of the Indian cities lack adequate capacity to transport it and there are no sanitary landfills to dispose-off the waste (NEERI, 1999). In the last few decades, the amount of waste generated per capita has recorded an annual increase at a rate of 1 to $1.33 \%$ (Shekdar, 1999). If this rate of increase continues, India will probably experience a rise in waste generation from less than 40,000 tons per year to over 125,000 tons by 2030 (Srishti, 2000). If an adequate MSWM strategy is not in place, human and environmental health would be jeopardized. It has been generally observed that less attention is being given towards the increasing soil pollution due to improper management of solid waste in Jammu and Kashmir.

The wastes are mostly thrown into open fields, on roads and in water bodies. The improper waste management has changed the structure and quality parameters of water bodies. The water holding capacity has been reduced due accumulation of wastes at bottom. Wastes have a well defined history to change the physicochemical structure of soils and water. Least attention has been given to the MSWM in underdeveloped countries and in Kashmir particular. So far only one scientific landfill unit has been constructed in Kashmir region. The study has been conducted to provide appropriate status of MSW generation records and waste management strategy in four adjacent districts in Kashmir region of Jammu and Kashmir.

\section{Methodology}

\section{Study Areas}

Srinagar is the largest city and the summer capital of the state Jammu and Kashmir. It lies on both the sides of river Jhelum, which is called Vyeth in Kashmir. The river passes through the city and meanders through the valley, moving onward and deepening in the Dal Lake.
There are a number of lakes and swamps in and around the Srinagar city. These include the Dal, the Nigeen, the Anchar, Khushal Sar, Gil Sar and Hokersar. Srinagar has a humid subtropical climate, much cooler than what is found in the rest of India, due to its moderately high elevation and northerly position. Winters are cool, with average day temperature of $2.5^{\circ} \mathrm{C} \quad\left(36.5^{\circ} \mathrm{F}\right)$ and temperatures below freezing at night. Moderate to heavy snowfall occurs in winter and summers are warm with average day temperature of $24.1^{\circ} \mathrm{C}\left(75.4^{\circ} \mathrm{F}\right)$. The average annual rainfall is around 710 millimeters. Spring is the wettest season while autumn is the driest.

Ganderbal district is at a distance of $21 \mathrm{~km}$ from Srinagar city. It is rich in landscape and is often called the District of Lakes, as it possesses the highest number of lakes in the state of Jammu and Kashmir. It is spread across the river Sind. The river is considered as the lifeline of the district. The river provides water for irrigation, $80 \%$ population of the district is engaged with farming. Ganderbal district possesses all the typical characteristics of the climate of Kashmir Valley as a whole. In the heat of July, the breeze of the Sind River is a welcome relief. The famous fresh water lakes located in district Ganderbal are Manasbal Lake, Gangabal Lake etc. The geographical coordinates and population according to Census, 2011 of study areas (four districts of Kashmir Valley) are depicted in Table 1.

Anantnag, locally known as Islamabad, is a district in the state of Jammu and Kashmir. It is located $65 \mathrm{~km}$ approximately from Srinagar city. It is the third most populous district in Kashmir valley. Anantnag features a moderate climate. Anantnag's climate is largely defined by its geographic location, with the towering Karokaram to its east and the Pirpanjal range to the south. It can be generally described as cool in the spring and autumn, mild in the summer and cold in the winter. The base of Pirpanjal is describing the origin of mighty river Jhelum. The geographical locations of study areas are depicted in Fig. 1.

District Budgam has tremendous tourism potential that has largely remained untapped so far. The attractive places that can be visited are Doodpather, Yusmarg, Tosmaidan, Nilnag and Khag. Here also the climate remains mild due to surrounding topography. The landscape is mostly agricultural type irrigated with fresh waters of river Doodhganga.

\section{Waste Collection and Pretreatment}

For the collection of samples; 20 houses were randomly selected in the main town from each district. Each household were provided by $10 \mathrm{Kg}$ capacity of polythene bag in the morning at 10.00 a.m. The same bags full of wastes were collected next day at 10.00.a.m, thus helping us to assess the amount of wastes generated from these units in $24 \mathrm{~h}$. The exercise was repeated five times i.e., after every 5 days of gap in a month. 
Table 1: Population and geographical attributes of sampling stations

\begin{tabular}{llc}
\hline Name of district & Geographical coordinates & Population \\
\hline Srinagar & $34^{\circ} 5^{\prime} 24^{\prime \prime} \mathrm{N} 74^{\circ} 47^{\prime} 24^{\prime \prime} \mathrm{E}$ & $1,250,173$ \\
Anatnag & $33.73^{\circ} \mathrm{N} 75.15^{\circ} \mathrm{E}$ & $1,069,749$ \\
Budgam & $34^{\circ} 1^{\prime} 12^{\prime \prime} \mathrm{N} 74^{\circ} 46^{\prime} 48^{\prime \prime} \mathrm{E}$ & 755,331 \\
Ganderbal & $33.73^{\circ} \mathrm{N} 75.15^{\circ} \mathrm{E}$ & 297,003 \\
\hline
\end{tabular}

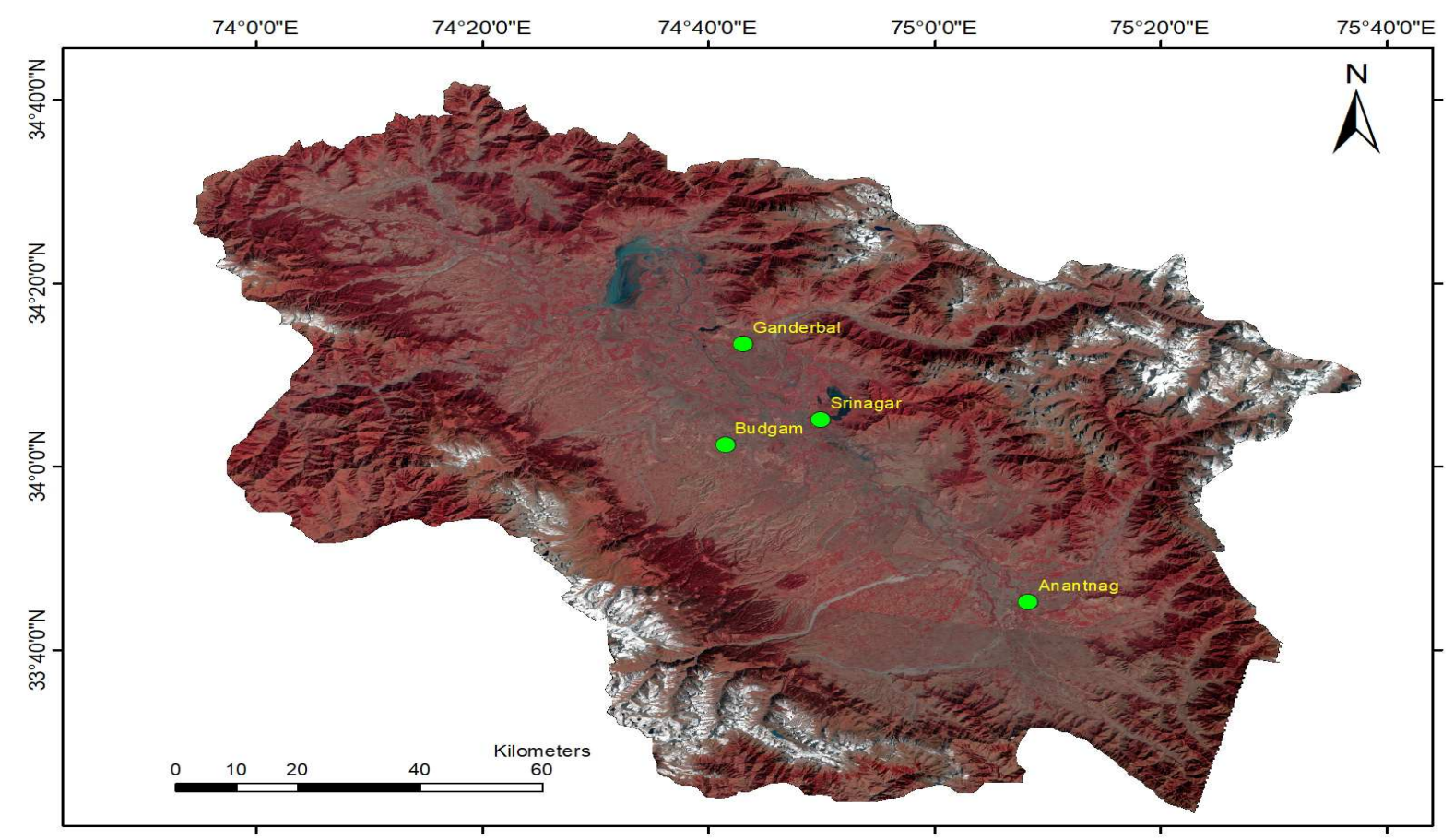

Fig. 1: Geographical locations of sampling stations

All the samples were transported with immense care to the laboratory for determination of moisture (at $105^{\circ} \mathrm{C}$ ) as per the standard methods (Gaxiola et al., 1995; Rampal et al., 2002; Benitez et al., 2003; Bhat et al., 2014). To investigate the composition and constituents of generated wastes; the samples collected were manually sorted and segregated into compostable, recyclable, combustible and inert categories. For the generation of MSW on per capita/day basis population of all the four districts has been calculated using the district-village population criteria.

\section{Laboratory Analysis}

For each type of waste, triplicate samples were analysed for moisture content, net weight composition (\%) and net weight $(\mathrm{Kg})$ or dried weight $(\mathrm{Kg})$. The moisture content $(\%)$ of the samples was determined with the following standard procedure and formula adopted by (Aarne et al., 1994). It was determined after drying the waste material at $105^{\circ} \mathrm{C}$ for $24 \mathrm{~h}$ (and at a temperature of 70 to $75^{\circ} \mathrm{C}$ in case of combustible material). The dried sample was expressed as a percentage of total weight. The formulas used for the measurement of above mentioned parameters are given below:

$$
\begin{aligned}
& \text { Weight of particular } \\
& \text { Net weight composition }(\%)=\frac{\text { constituent of MSW }}{\text { Total weight of constituents }} \times 100 \\
& \text { Moisture content }=\frac{\left(W_{w}-W_{d}\right)}{W_{w}} \times 100 \\
& \text { Net weight }(\mathrm{Kg})=W_{w}-\frac{\left(\text { Moisture content } \times W_{w}\right)}{100}
\end{aligned}
$$

(where, $W_{w}$ represents wet weight of the waste and $W_{d}$ dried weight of waste).

\section{Results and Discussion}

\section{Waste Generation}

The MSW generated, reflected remarkable differences in waste constituents, composition with respect to population and location (district). The data 
depicted in Table 2 revealed that among the four districts, Srinagar generated the highest amount of waste with an average $0.526 \mathrm{~kg} /$ person/day of MSW followed by Anantnag $(0.479 \mathrm{~kg} /$ person/day $)$ and Ganderbal $(0.400 \mathrm{~kg} /$ capita/day $)$. The generation of MSW was recorded least in case of Budgam with an average of $0.397 \mathrm{~kg} /$ capita/day. The quantity of MSW generated per year in Srinagar city was highest (236, 732.75 MT) followed by Anantnag (184, 467.34 MT), Budgam (107,251.20 MT) and least was observed in district Ganderbal (42,840.00 MT) data is shown in Table 3. High moisture content (Fig. 2) was recorded in food items in all four districts in the range of 41 to $47 \%$. The cardboard paper contained moisture content in the range of 18 to $22 \%$. In all the districts, the moisture content was observed least in case of plastic and polythene of about 6 to 7\%. The Kashmir valley as a part of developing country (India) is a very beautiful region of sate Jammu and Kashmir. The rate at which MSW is generated here may destruct the quality of scenic beauty and ecosystem structures. The purpose of this research was to evaluate the quantity, composition, sources of waste generated, their current disposal practices, management strategies and the problems associated with municipal solid wastes in four districts of Kashmir Valley. Rapid economic and population growth is responsible for the generation of solid waste. Similar findings regarding waste generation differences among socioeconomic areas where the higher socioeconomic classes generated higher waste (Asase, 2011). The Srinagar city is the most developed district among the four districts and it is the commercial hub of Kashmir Valley. The basic requirements for sustaining living standard are easily available in Srinagar city which is responsible for enhancing the waste generation in this particular district. Municipal or domestic wastes are frequently generated from numerous sources where inconsistent human behaviours are encountered. Several studies indicate that much of the municipal solid waste from developing countries are generated from households (55$80 \%$ ), followed by commercial or market areas (10-30\%) with varying quantities from streets, industries, institutions (Nabegu, 2010; Nagabooshnam, 2011; Okot-Okumu, 2012). MSWM is a major issue affecting both developed and undeveloped economies due to the increasing amount of wastes generated annually. Increases in waste generation are often associated with economic growth, higher industrialization, rise in population and higher standards of living (Minghua et al., 2009). Furthermore, there are various types of industries, huge markets, shopping malls, transport yards, hotels, restaurants, congested built-up, huge population etc., located in the vicinity area that also boost generation rates of MSW. Economic development, urbanization and improving living standard in cities of developing countries have lead to increase in the quantity and complex composition of MSW (Khajuria et al., 2010). The tourist influx both foreigners and national in Srinagar city could be attributed to high rates of MSW. Rapid population growth and expanding urbanization have caused a drastic increase of the MSW generation and the variety of the waste composition (Nguyen et al., 2011).

Table 2: The mean (kg/capita/day) MSW generation in different districts

\begin{tabular}{lllll}
\hline Waste constituents & Srinagar & Anantnag & Ganderbal & Budgam \\
\hline Food items & 0.107 & 0.095 & 0.08 & 0.085 \\
Cardboard paper & 0.080 & 0.053 & 0.049 & 0.050 \\
Plastic and polythene & 0.063 & 0.055 & 0.043 & 0.041 \\
Wooden items & 0.060 & 0.065 & 0.052 & 0.057 \\
Paper & 0.055 & 0.048 & 0.041 & 0.037 \\
Metals & 0.053 & 0.051 & 0.042 & 0.041 \\
Rubber and leather & 0.015 & 0.010 & 0.010 & 0.021 \\
Bones and shells & 0.047 & 0.056 & 0.051 & 0.045 \\
Glass & 0.025 & 0.031 & 0.020 & 0.010 \\
Others & 0.021 & 0.015 & 0.012 & 0.010 \\
Total & 0.526 & 0.479 & 0.40 & 0.397 \\
\hline
\end{tabular}

Table 3: MSW generated (Metric Tons per year) in different districts along with population status

\begin{tabular}{lll}
\hline District & Population & Waste Generated in (MT) \\
\hline Srinagar & $1,250,173$ & $236,732.75$ \\
Anantnag & $1,069,748$ & $184,467.34$ \\
Ganderbal & 297,503 & $42,840.00$ \\
Budgam & 755,331 & $107,951.90$ \\
Total & $3,372,755$ & $571,991.99$ \\
\hline
\end{tabular}




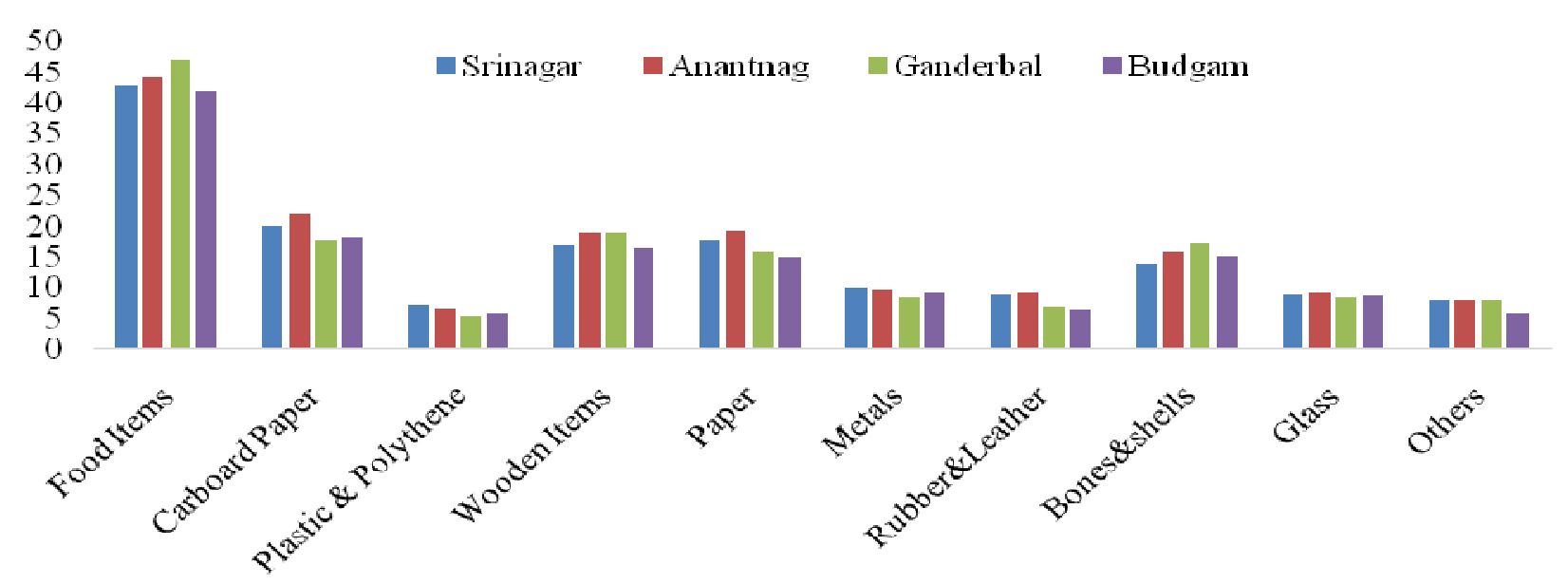

Fig. 2: Moisture content (\%) of waste constituents in different districts

\section{Waste Composition}

The waste constituents were categorized into recyclable, compostable and inert materials (having negative economic value). Every district contributes a bulk share of MSW in the form of recyclable wastes. Among the four districts, Srinagar city contributed highest to generate recyclable waste about $152,121.05$ MT per year followed by district Anantnag (117,073.22 MT per year), Budgam (66,620.2 MT per year) and least was observed in district Ganderbal $(27,417)$ MT per year. The compostable, combustible and inert materials were also observed highest $(48,156.6,27003.6$ and 745.31 MT per year) in Srinagar city and least $(8,568.1,5,567.26$ and 1 , 285.21 MT per year) was observed in Ganderbal as shown in Table 4. The category wise contribution was observed highest rank for recyclable 62 to 64 followed by compostable 20 to $21 \%$ and least was observed for inert material 3 to $4 \%$ in all the districts Fig. 3(a-d). The weight percent contribution of waste constituents was observed highest (20 to $22 \%$ ) for food wastes, followed by cardboard paper (11 to $15 \%$ ) and least was observed in case of other miscellaneous (3 to 4\%) in all four districts as shown in Fig. 4(i-iv). Waste generation differs between economies. Increasing population levels, booming economy, rapid urbanization and the rise in community living standards have greatly accelerated the municipal solid waste generation rate in developing countries (Minghua et al., 2009). Developed countries generally have higher waste generation rates than undeveloped ones. Growth of population, increasing urbanization, rising standards of living due to technological innovations have contributed to an increase both in the quantity and variety of solid wastes generated by industrial and domestic activities (Pappu et al., 2007). Besides waste generation, waste composition is an important parameter in the development of proper waste management strategies. MSW is generated as a result of economic growth, development and consumption. The composition and volume of wastes varies from one city to another and that these variations are due to the different patterns of consumption, wastes production index, composition of the population, socioeconomic and cultural level and in large measure to the influence of the consumption patterns (Berneche-Perez et al., 2001; Buenrostro et al., 2001). Countries with higher income generate more MSW per capita per day basis and their waste have higher portions of packaging materials and recyclable wastes, while in case of developing countries, the proportion of compostable and recyclable wastes are very high. MSW includes degradable (paper, textiles, food waste, straw and yard waste), partially degradable (wood, disposable napkins and sludge, sanitary residues) and non-degradable materials (leather, plastics, rubbers, metals, glass, ash from fuel burning like coal, briquettes or woods, dust and electronic waste) (Heart, 2009; Jha et al., 2007; Tchobanoglous et al., 1993; Valkenburg et al., 2008). People in this region like to eat cooked rice most than any other food item and used to eat it twice in a day. The food wastes bears lot of moisture that contributes to the MSW to a great extent. In most developing countries the highest percentage (40-70\%) of MSW consists of organic matter, which is able to retain a high moisture content (Sivapalan et al., 2002); (Agamuthu et al., 2007); (Thitame et al., 2010); Ganeshwaran and Shri, 2015). 


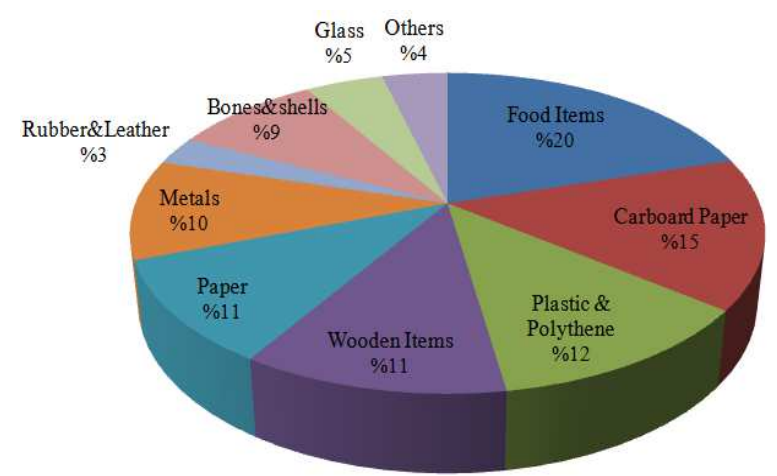

(a)

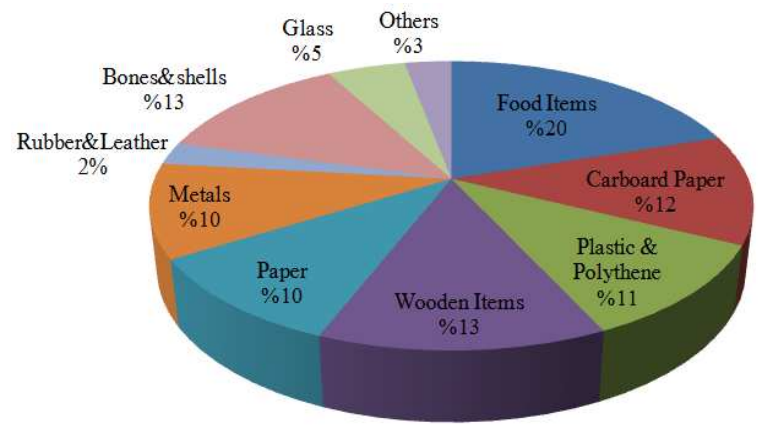

(c)

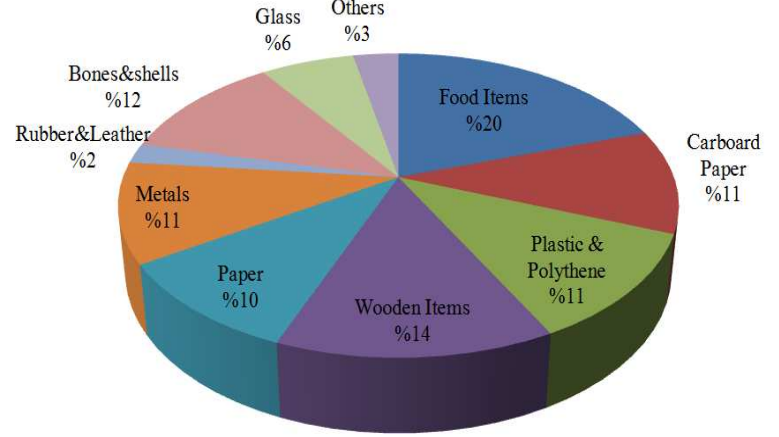

(b)

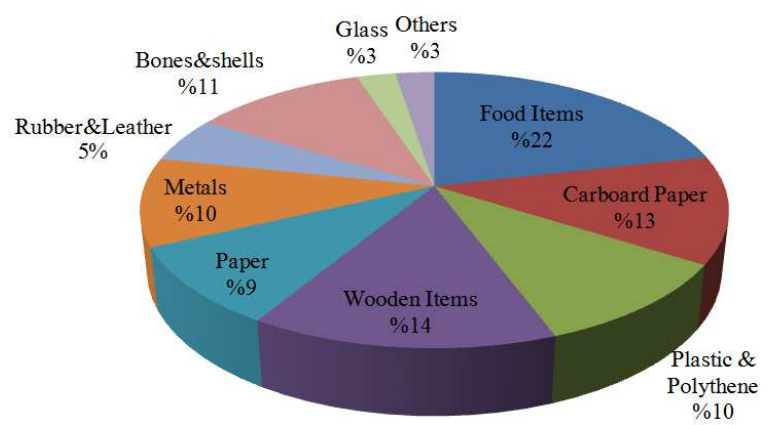

(d)

Fig. 3: (a) Srinagar (b) Anantnag (c) Ganderbal (d) Budgam weight percentage contribution of waste constituents

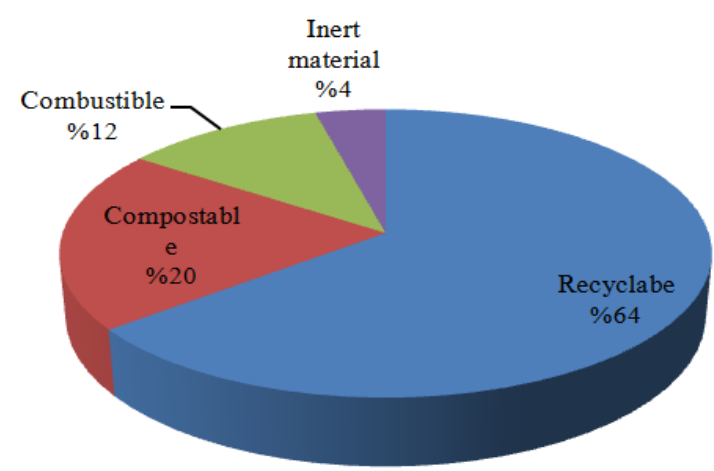

(a)

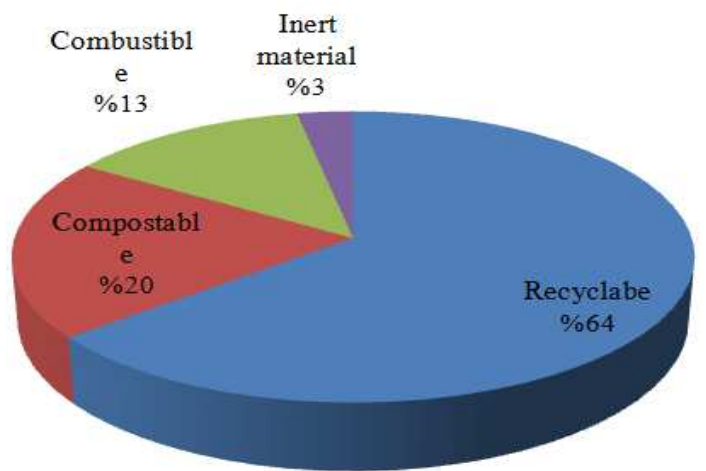

(c)

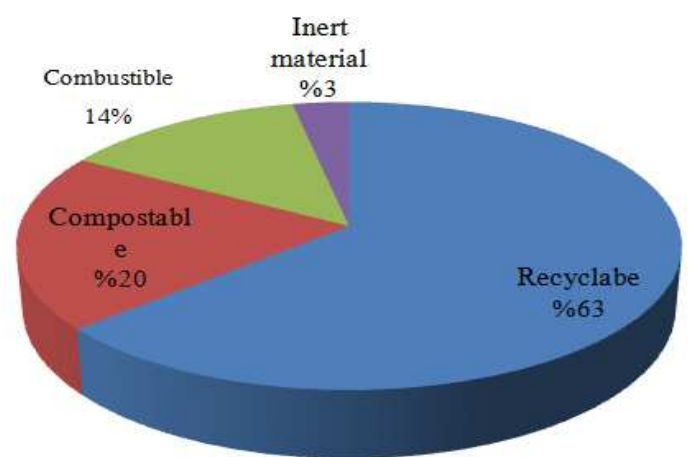

(b)

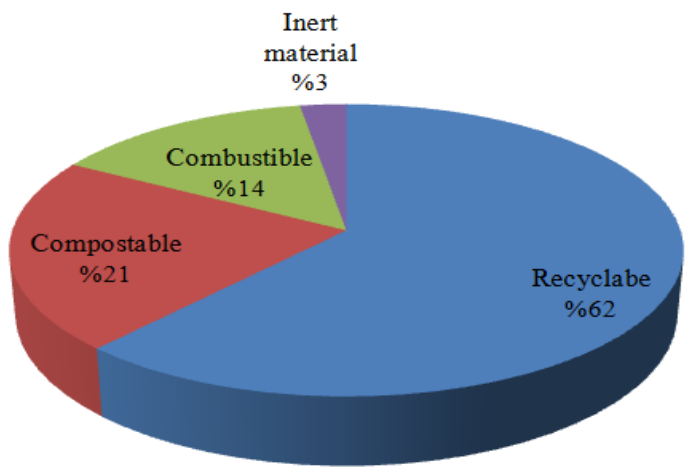

(d)

Fig. 4: (a) Srinagar (b) Anantnag (c) Ganderbal (d) Budgam waste category contribution (\%) in different districts 
Table 4: Category of MSW for waste management systems

\begin{tabular}{|c|c|c|c|c|}
\hline \multirow[b]{2}{*}{ Category of waste } & \multicolumn{4}{|c|}{ Metric Tons (MT) } \\
\hline & Srinagar & Anantnag & Ganderbal & Budgam \\
\hline Recyclable & $152,121.05$ & $117,073.22$ & $27,417.00$ & $66,620.20$ \\
\hline Compostable & $48,156.60$ & $36,585.30$ & $8,568.10$ & $23,113.13$ \\
\hline Combustible & $27,003.76$ & $25,032.00$ & $5,569.26$ & $15,499.39$ \\
\hline Inert material & $9,451.31$ & $5,776.63$ & $1,285.21$ & $2,719.19$ \\
\hline
\end{tabular}

Srinagar city is a developed hub and occupy highest position as for as basic and other facilities are concerned. The developed structure in the form of gadget availability is highest in Srinagar city. People used to buy all the new gadgets in and other daily need items contained tin containers, cardboards, paper boxes, plastics items and paper and polythene wrappers. The waste composition depends on a wide range of factors such as habitats, culture tradition, lifestyle, climate and income (Gupta et al., 1998). Waste constituents (egg shells, bones, etc.) contributed very much to the recyclable waste materials. The major fraction of MSW comprised of organics (44\%) followed by recyclables namely paper, plastics, glass and metals; total: $43 \%$ (Mohee et al., 2015; Ojeda-Benitez et al., 2003). From the waste composition data, the recyclability, combustibility or biodegradability of the waste streams can be identified and these can be subsequently used for designing and implementing appropriate waste management technologies. Small Island Developing States (SIDS) regions whereby it can be observed that the waste compositions differ only slightly among the three geographic regions owing to possible similarities in consumption patterns adopted by people living in SIDS (Chandrappa and Das, 2012). The high contribution of recyclable materials in the MSW generated in these districts could be due to the excessive use of plastic items, glass, paper, cardboard, etc. Recyclable materials contributed most in MSW (Mohee et al., 2015). Food is the lifeline to every form of life and is the most important consumable on daily basis; with the result it contributes lot to the MSW. Food waste is a major constituent with high percentage among the all constituents of MSW (Agamuthu et al., 2007; Bhat et al., 2013).

\section{Waste Collection}

Waste collection is a most vital useful component of the waste management system. Waste collection, transfer and transport are important but expensive municipal services (Faccio et al., 2011). The lack of a proper waste collection system absolutely disrupts the waste management course. Waste collection is a highly visible municipal service that involves large expenditures and difficult operational problems, plus it is expensive to operate in terms of environmental costs i.e., emissions, noise and traffic congestions (Faccio et al., 2011). The waste collection is only performed in Srinagar city and is almost negligible in other districts in Kashmir valley. The Srinagar Municipal Corporation (SMC) has the mandate for waste management system in Srinagar city. The SMC has provided the small waste-bins to every household and the same bins were collected in daily routine basis. The collected waste is transported into the landfill site near Achan area in the Srinagar outskirts. Waste segregations into different categories viz., composting, recycling, combustible, etc. yet not practiced in Srinagar, though the authority is collecting and dumping the waste since 1984 . The other districts (Anantnag, Budgam and Ganderbal) were lacking this facility as collection of waste is done around the main towns and dumped into the nearby water bodies, open fields or sometimes dumped directly into the fresh water bodies.

The unwanted practices like dumping at prohibited areas viz., fresh water bodies, agriculture lands, forests, road sides and burning of wastes could lead to environmental pollution; the health and environmental implications are associated with SWM are mounting in urgency, particularly in the context of developing countries (Marshall and Farahbakhsh, 2013). These practices may indirectly alter the physicochemical characteristics of fresh water bodies and soils. The degraded waste could lead to release leachate having high concentration of chemical and other toxic substances. In most of the developing countries, MSW disposal has been a chronic problem and are being continuously added to water bodies hence affect the physiochemical quality of water making it unfit for use of livestock and other organisms (Sadek and El-Fadel, 2000; Muhibbu-Din et al., 2011). Besides, unscientific dumping of waste could choke the flowing water bodies and likely could affect the normal water holding potential of static water bodies. These practices are common and pose severe ecological and health effects due to the release of toxic emissions during burning and the spread of diseases from illegal dumping (ADB, 2014). All these shortcomings also affect the waste transfer and transport processes. Since the vehicles used for the transfer and transport of waste suffer from poor maintenance, the effectiveness of the transfer and transport processes is greatly reduced. Following the transfer process, the wastes are then transported for ultimate disposal into the sea or in dump sites since transfer stations are almost non-existent in many SIDS (UNEP, 1999); (ADB, 2014). 


\section{Transportation}

Dumping of MSW on the roadside or in other public places is a regular practice in developing countries; cleanness is an important movement in the wastemanagement system. In Srinagar city, once collected, MSW is carried out by using different types of vehicles depending on the distances to be covered by them. Larger vehicles carry the waste from the collection points to the disposal sites. The transportation of garbage from the transfer stations is done generally using trucks. In large areas, open trucks, covered trucks, closed containers and some compactors are in use, whereas in smaller access areas hand-carts are in use. Usually liquid is spill out from the vehicles carrying the MSW which turns the clean roads into focal point of disease carried by various mobile vectors like insects. Same is the case with other districts as well. Comparing to Srinagar City, the other districts are very poor as for as transportation of MSW are concerned. They usually carry out the MSW in agricultural tractors with the result littering of MSW is common. These districts have large number of fresh water bodies in their surrounding areas. The MSW in these districts are either dumped in the vicinity of water bodies or sometimes directly thrown into the water bodies. The sanitary or scientific landfill is a concept far beyond the scope in these districts.

\section{Disposal}

Almost all municipal waste collected from different areas is taken to lone landfill site located in Achan area of Srinagar outskirts. The landfill site is located very close to the Anchar Lake with water table not more than $1 \mathrm{~m}$ depth. Before 2007, the MSW were dumped to the same location without having any engineering or sanitary landfill. There could be a clear case of contamination of Anchar lake and this could be one possible reason behind the premature aging of Anchar lake. The operation and maintenance at Achan sanitary landfill is very poor. Though the authorities have installed 3 numbers of leachate treatment plants, but could not control the spill out leachate from the site and posing an enormous health threat to local populations due to soil, ground and surface water contamination from untreated leachate. The most commonly reported danger to the human health from these landfills is from the use of groundwater that has been contaminated by leachate (Rajkumar et al., 2010). The waste covering at Achan land fill site is very poor which results emanating of stench and make whole vicinity prone to health hazard. Paddy and many types of vegetables and crops are grown in the vicinity. There could be a possible contamination from the landfill to the crops and vegetables grown near to the landfill site. The main environmental problem associated with the disposal sites are the potential risks posed to the soil and number of contaminants including heavy metals readily penetrate and eventually they contaminate the soil and affect vegetation abundance of the area (Ali et al., 2014). The authorities is not yet taking any step to collect the methane $\left(\mathrm{CH}_{4}\right)$ gas which is more than 40 times potent of global warming gas than carbon-dioxide $\left(\mathrm{CO}_{2}\right)$ generating from the landfill site. A landfill generates $50-65 \%$ by volume $\mathrm{CH}_{4}$ gas hence is a concern to the local authorities as well as country level. $\mathrm{CH}_{4}$ and nitrous oxide $\left(\mathrm{N}_{2} \mathrm{O}\right)$ emissions are associated with microbial processes in MSW and are strongly affected by oxygen $\left(\mathrm{O}_{2}\right)$ status, moisture, $\mathrm{pH}$, temperature and organic carbon $(\mathrm{C})$ and Nitrogen $(\mathrm{N})$ form and availability (Hellebrand, 1998; Beck-Friis et al., 2000; 2003; Jäckel et al., 2005; Zhu et al., 2008). MSW decomposition, only large landfill sites will be able produce methane at a high level over a long period of time (IEA, 2008). The other districts yet not have constructed any landfill site for the scientific disposal of MSW. The collected waste is directly dumped into the open fields sometimes disposed off near to the fresh water bodies. In general there is a poor waste management scenario in Kashmir Valley.

\section{Conclusion}

Economic development, unplanned urbanization patterns and material consumption drastically enhance the MSW generation rates. The poor waste management strategies, economic development lack of infrastructure, material, consumption levels and unawareness were responsible for increasing and littering of MSW in Kashmir Valley and could leads to the permanent degradation of environmental quality. Srinagar is the unique district practicing landfilling of MSW in Achan area, with ample shortcomings in the form of leachate spill out, site location, improper handling of operation and maintenance. The valley is facing tremendous pressure associated with problems of growing waste generation. The need of hour is to save the scenic beauty of fragile ecosystem from the waste disposal hazard.

\section{Acknowledgements}

The authors would like to express their sincere gratitude to the scholars of Division of Environmental Sciences, Sher-e-Kashmir University of Agricultural Sciences and Technology, Shalimar-Kashmir for their kind help during the study period of this research work.

\section{Author's Contributions}

All authors equally contributed in this work. 


\section{Ethics}

This article is original and contains unpublished material. The corresponding author confirms that all of the other authors have read and approved the manuscript and there are no ethical issues involved.

\section{References}

Aarne, P.V., J.P. Jeffrey and F.W. Ruth, 1994. Environmental Engineering. 3rd Edn., Boston: Butterworth Heinemann.

ADB, 2014. Solid Waste management in the pacific. Appropriate technologies. Asian Development Bank.

Agamuthu, P., S.H. Fauziah, K.M., Khidzir and A.A. Noorazamimah, 2007. Sustainable waste management Asian perspectives. Proceedings of the International Conference on Sustainable Solid Waste Management, Sep. 5-7, Chennai, India, pp: 15-26.

Ali, S.M., P. Pervaiz, B. Afzal, N. Hamid and A. Yasmin, 2014. Open dumping of municipal solid waste and its hazardous impacts on soil and vegetation diversity at waste dumping sites of Islamabad city. J. King Saud Uni. Sc., 26: 59-65.

Asase, M.A.D., 2011. Solid waste separation at source: A case study of the Kumasi Metropolitan Area. thesis submitted to the Chemical Engineering Department, Kwame Nkrumah University of Science and Technology, Kumasi, in partial fulfillment of the requirements for the Degree of Doctor of Philosophy, Faculty of Chemical and Materials Engineering, College of Engineering.

Beck-Friis, B., M. Pell, U. Sonesson, H. Jönsson and H. Kirchmann, 2000. Formation and emission of $\mathrm{N}_{2} \mathrm{O}$ and $\mathrm{CH}_{4}$ from compost heaps of organic household wastes. Environ. Monit. Assess., 62: 317-331.

Beck-Friis, B., S. Smårs, H. Jönsson, Y. Eklind and H. Kirchmann, 2003. Composting of source separated household organics at different oxygen levels: Gaining an understanding of the emission dynamics. Compost. Sci. Util., 11: 41-50.

Benitez, S.O., C.A., de-Vega and M.E.R. Barreto, 2003. Characterization and quantification of household solid waste in a Maxican city. Res. Conserv. Recy., 39: 211-222.

Berneche-Perez, G., S.C. Salvadro, G.A. Maria, D.V. Artruro and S.S.M. Elena, 2001. Solid waste characterization study in the Guadalajara metropolitan zone, Mexico. Waste Manage. Res., 19: 413-424.

Bhada-Tata, P. and D. Hoornweg, 2011. A compilation of global MSW generation rates and composition: projections and policy recommendations. Proceedings of the Waste Safe 2011 2nd International Conference on Solid Waste Management in the Developing Countries, Feb. 13-15, Khulna, Bangladesh.
Bhat, R.A., A.N. Kamili and S.A. Bandh, 2013. Characterisation and composition of Municipal Solid Waste (MSW) generated in Yusmarg: A health resort of Kashmir valley: A Glance at the World. Waste Manage., 33: 774-777.

Bhat, R.A., G.A. Dar, A. Jehangir, B.A. Bhat and A.R. Yousuf, 2012. Municipal solid waste generation and present scenario of waste management during Yatra season in Pahalgam: A tourist health resort of Kashmir valley. Int. J. Cur. Res., 4: 004-009.

Bhat, R.A., R. Nazir, S. Ashraf, M. Ali and S.A. Bandh et al., 2014. Municipal solid waste generation rates and its management at Yusmarg forest ecosystem, a tourist resort in Kashmir. Waste Manage. Res., 32: 165-169.

Buenrostro, O., B. Gerardo and B. Gerardo, 2001. Urban solid waste generation and disposal in Mexico: A case study. Waste Manage. Res., 19: 169-176.

Chandrappa, R. and D.B. Das, 2012. Waste Quantities and Characteristics. In: Solid Waste Management, Chandrappa, R. and D.B. Das (Eds.), SpringerVerlag, Heidelberg, pp: 53.

Faccio, M., A. Persona and G. Zanin, 2011. Waste collection multi objective model with real time traceability data. J. Waste Manage., 31: 2391-2405.

Ganeshwaran, P. and S.D. Shri, 2015. A solid waste management in Coimbatore city. ARPN J. Eng. Applied Sci., 10: 6177-6183.

Gaxiola, H., P.Y. de-Consume and B.E. Mexicali, 1995. Tesisinedita de maestris en arquitectura. Universidad Autonoma de Baja California, Maxicali.

Gupta, S., M. Krishna, R.K. Prasad, S. Gupta and A. Kansal, 1998. Solid waste management in India: Options and opportunities. Res. Conserv. Recy., 24: 137-154.

Heart, S., 2009. Electronic waste: An emerging issue in solid waste management in Australia. Int. J. Environ. Waste Manage., 3: 120-134.

Hellebrand, H.J., 1998. Emission of nitrous oxide and other trace gases during composting of grass and green waste. J. Agr. Eng. Res., 69: 365-375.

IEA, 2008. Turning a liability into an asset: Landfill methane utilization potential in India. Int. Energy Agency.

Jäckel, U., K. Thummes and P. Kämpfer, 2005. Thermophilic methane production and oxidation in compost. Fems Microbiol. Ecol., 52: 175-184.

Jain, P.K., 1994. Waste management in Delhi. Civil Affairs, 31: 51-57.

Jha, K., A.C. Sharma, N. Singh, R. Ramesh and R. Purvaja et al., 2007. Greenhouse gas emissions from municipal solid waste management in Indian megacities: A case study of Chennai landfill sites. Chemosphere, 71: 750-758. 
Khajuria, A., Y. Yamamoto and T. Morioka, 2008. Solid waste management in Asian countries: Problems and issues. Waste Manage. Environ., 109: 643-653.

Khajuria, A., Y. Yamamoto and T. Morioka, 2010. Estimation of municipal solid waste generation and landfill area in Asian developing countries. J. Environ. Bio., 31: 649-654.

Marshall, R.E. and K. Farahbakhsh, 2013. Systems approaches to integrated solid waste management in developing countries. Waste Manage., 33: 988-1003.

Minghua, Z., F. Xiumin, A. Rovetta, H. Qichang and F. Vicentini et al., 2009. Municipal solid waste management in Pudong New Area, China. Waste Manage., 29: 1227-1233.

Mohee, R., S. Mauthoor, Z.M.A. Bundhoo, G. Somaroo and N. Soobhany et al., 2015. Current status of solid waste management in small island developing states: A review. Waste Manage., 43: 539-549.

Muhibbu-Din, O.I., A.O. Aduwo and A.A. Adedeji, 2011. Study of physiochemical parameter of effluent impacted stream at obafemi awolowo university IleIfe, Nigeria. Obafemi Awolowo University, Ile-Ife, Osun State, Nigeria.

Nabegu, A.B., 2010. An analysis of municipal solid waste in Kano metropolis, Nigeria. J. Hum. Ecolo., 31: 111-119.

Nagabooshnam, J.K.., 2011. Solid waste generation and composition in Gaborone, Botswana, Potential for resource recovery. $\mathrm{PhD}$ Thesis, Linkoping University.

NEERI, 1999. Report on "strategy paper on solid waste management in India.

Nguyen, P.T., M. Yasuhiro and F. Takeshi, 2011. Assessment of plastic waste generation and its potential recycling of household solid waste in Can Tho City, Vietnam. Environ. Monit. Asses., 175: 23-35.

Ojeda-Benitez, S., C.A. de-Vega and M.E. RamırezBarreto, 2003. Characterization and quantification of household solid wastes in a Mexican city. Res. Cons. Rec., 39: 211-222.

Okot-Okumu, J., 2012. Solid Waste Management in African cities - East Africa. 1st Edn., INTECH Open Access Publisher. ISBN-10: 953510795X.

Pappu, A., M. Saxena and S.R. Asolekar, 2007. Solid wastes generation in India and their recycling potential in building materials.

Rajkumar, N., T. Subramani and L. Elango, 2010. Groundwater contamination due to municipal solid waste diposal: A GIS based study in Erode City. Int. J. Environ. Sci., 1: 39-55.

Rampal, R.K., J. Kour and R. Jamwal, 2002. Solid waste Generation in Government Hospitals of Jammu city India. Pollution Res., 21: 39-43.

Sadek, S. and M. El-Fadel, 2000. The Normandy Landfill: A case study in solid waste management. J. Nat. Resour. Life Sci. Educ., 29: 155-61.
Shekdar, S., 1999. Municipal solid waste management the Indian perspective. J. Indian Association Environ. Management, 26: 100-108.

Sivapalan, K., M.Y. Noor, S. AbdHalims, S. Kamurazzaman and A.R. Rakmi, 2002. Comprehensive characteristics of the MSW generated in Kuala Lumpur. Proceedings of the Regional Symposium on Environment and Nature Resources, pp: 359-368.

Srishti, 2000. Fifth Srishti survey of medical waste disposal practices in health care units of Delhi. New Delhi.

Tchobanoglous, G., H. Theisen, S.A. Vigil, 1993. Integrated Solid Waste Management, Engineering Principles and Management Issues, McGraw Hill International edition. McGraw-Hill Companies, Singapore.

Thitame, S.N., G.M. Pondhe and D.C. Meshram, 2010. Characterisation and composition of Municipal Solid Waste (MSW) generated in Sangamner City, District Ahmednagar, Maharashtra, India. Environ. Monit. Assess., 170: 1-5.

UNEP, 1999. Guidelines for municipal solid waste management planning in small island developing states in the Pacific region. Apia, Samoa: South Pacific Regional Environment Programme.

Valkenburg, C., C.W. Walton, B.L. Thompson, M.A. Gerber and S. Jones et al., 2008. Municipal Solid Waste (MSW) to liquid fuels synthesis, Volume 1: Availability of feedstock and Technol. PNNL 18144, Pacific Northwest National Laboratory, Richland, WA.

Visvanathan, C., J. Trankler, K. Joseph, C. Chiemchaisri and B.F.A. Basnayake et al., 2004. Municipal solid waste management in Asia. Asian Regional Research Program on Environmental Technology (ARRPET). Asian Institute of Technology publications.

Zhu, D., P.U. Asnani, C. Zurbrugg, S. Anapolsky and S. Mani, 2008. Improving Solid Waste Management in India: A Sourcebook for 740. Policy Makers and Practitioners; WBI Development Studies; World Bank Institute, The World Bank: Washington, DC, USA, pp: 739-741. 